\title{
IDENTIFIKASI BAHAYA DI LABORATORIUM SISTEM TENAGA ELEKTRIK DENGAN METODE PENILAIAN KUANTITATIF DET NORSKE VERITAS DAN 3D MODEL
}

\author{
Abdurachman Effendi ${ }^{1 *}$ \\ ${ }^{1}$ Jurusan Teknik Elektro Fakultas Teknik Universitas Lampung-Bandar lampung 35154 \\ Laboratorium Sistem Tenaga Elektrik \\ * E-mail : abdurachmaneffendi@yahoo.com ${ }^{1}$
}

\begin{abstract}
Abstrak
PLP, laboran dan teknisi laboratorium pendidikan yang bertugas di perguruan tinggi dan sekolah, rentan terhadap risiko keselamatan dan kesehatan saat melaksanakan tugas dan fungsinya. Data mengklarifikasi beberapa kasus kecelakaan yang berakibat cidera pada korban terjadi di laboratorium pendidikan.. Hazard di laboratorium membutuhkan penerapan instrument keselamatan dan kesehatan kerja yang benar dan berkelanjutan. Aktivitas praktikum dan penelitian di laboratorium sistem tenaga elektrik sebagian besar menggunakan peralatan yang dengan supplai listrik bertengangan $220 \mathrm{~V}$ hingga $380 \mathrm{~V}$. Kesalahan kecil yang terjadi saat mengoperasikan peralatan dapat berisiko kecelakaan yang dapat mengakibatkan cidera bahkan kematian. Manajemen risiko diperlukan yang meliputi identifikasi bahaya, analisis potensi bahaya, penilaian risiko, dan pengendalian risiko. Identifikasi bahaya dan analisis potensi bahaya dilakukan dengan menggunakan metode penilaian kuantitatif yang diterbitkan oleh Det Norske Veritas dan 3D Model. Penilaian tingkat resiko dilakukan berdasarkan parameter peluang, kuantitas dan kegawatan dari risiko bahaya. Penelitian ini menyimpulkan potensi bahaya pada Laboratorium Sistem Tenaga Elektrik Juru san Teknik Elektro Fakultas Teknik Universitas Lampung pada level bahaya sedang dan rendah.
\end{abstract}

Kata Kunci: keselamatan,kesehatan,laboratorium, resiko kerja.

\begin{abstract}
Pranata Laboratorium Pendidikan (PLP), laboratory assistant and laboratory technicians who assigned in higher institutions and schools are risky to safety and health risks during working. Accidents that occur in the laboratory cause in permanent injuries, mild, or health problems. Hazard in the laboratory requires the right and sustainable implementation of safety and health on running the instrument. Practical and research activities in the laboratory of electrical power systems mostly use equipment operated by $220 \mathrm{~V}$ up to $380 \mathrm{~V}$ power supply. Small mistakes that occured while operating the equipment can be risky accidents that cause in injury or even death. Risk management required which consists of hazard identification, hazard potential analysis, risk assessment, and risk control. Hazard identification and potential hazard analysis were conducted by using the quantitative valuation method published by Det Norske Veritas and 3D Model. Risk level assessment is based on probability, quantity and emergency of hazard risk. This study concludes that potential hazards at Laboratory of Electrical Power System in Electrical Engineering Faculty of Lampung University are on the low and mid hazard level.
\end{abstract}

Keywords: safety, health, laboratory, risk injury.

\section{Pendahuluan}

Mengutip pada Permenpan \& RB 03 tahun 2010 pasal satu angka tiga disebutkan bahwa laboratorium pendidikan yang selanjutnya disebut laboratorium adalah unit penunjang akademik pada lembaga pendidikan, berupa ruangan tertutup atau terbuka, bersifat permanen atau bergerak, dikelola secara sistematis untuk kegiatan pengujian, kalibrasi, dan/atau produksi dalam skala terbatas, dengan menggunakan peralatan dan bahan berdasarkan metode keilmuan tertentu, dalam rangka pelaksanaan pendidikan, penelitian, dan/atau pengabdian kepada masyarakat. Agar sebuah laboratorium pendidikan dapat melaksanakan fungsi sesuai definisinya maka laboratorium perlu dikelola secara baik dan profesional.

Menurut A. M.Sugeng Budiono (2005:171), kecelakaan kerja adalah suatu kejadian atau peristiwa yang tidak diinginkan yang merugikan terhadap manusia, merusak harta benda atau kerugian terhadap proses.

Dalam melaksanakan tugas dan fungsinya PLP, laboran dan teknisi laboratorium rentan terhadap resiko keselamatan dan kesehatan baik untuk personal, orang lain, peralatan dan bahan di laboratorium. Dalam melaksanakan tugas dan fungsinya PLP, laboran dan teknisi memberikan bimbingan cara pengoperasian, perawatan peralatan dan bahan yang sulit, risiko penggunaan tinggi, akurasi/kecermatan, pengukurannya tinggi serta sistem kerja rumit bahkan dalam pengoperasian beberapa jenis peralatan dan penggunaan bahan memerlukan pelatihan khusus dan tersertifikasi. Penelitian yang telah dilakukan di Politeknik Negeri Batam menyimpulkan 79,4\% mahasiswa menyatakan bahwa faktor keselamatan dan kesehatan kerja sangat penting diterapkan di laboratorium. Sebanyak 66,67 \% faktor lingkungan 
mempengaruhi keselamatan dan kesehatan kerja di laboratorium. Beberapa kasus kecelakaan ataupun menderita luka baik yang bersifat luka permanen, luka ringan, maupun gangguan kesehatan yang dapat menyebabkan penyakit kronis maupun akut, serta kerusakan terhadap fasilitas - fasilitas dan peralatan penunjang praktikum dan penelitian yang sangat mahal harganya mencerminkan tingkat resiko yang dapat dialami oleh tenaga laboratorium. Tingkat resiko kerja di sebuah laboratorium pendidikan dapat berpengaruh pada kualitas hidup tenaga laboratorium. Realitas potensi hazard di laboratorium yang tinggi membutuhkan penerapan sistem manajemen keselamatan dan kesehatan kerja yang benar dan berkelanjutan.

\section{Pengertian K3 dan SMK3}

K3 adalah singkatan dari Keselamatan dan Kesehatan Kerja yang dalam bahasa Inggris disebut sebagai Occupational Health and Safety, disingkat OHS. K3 atau OHS adalah kondisi yang harus diwujudkan di tempat kerja dengan segala daya upaya berdasarkan ilmu pengetahuan dan pemikiran mendalam guna melindungi tenaga kerja, manusia serta karya dan budayanya melalui penerapan teknologi pencegahan kecelakaan yang dilaksanakan secara konsisten sesuai dengan peraturan perundangan dan standar yang berlaku. Occupational Health and Safety Assessment Series menjabarkan pengertian Sistem Manajemen Keselamatan dan Kesehatan Kerja (SMK3) adalah bagian dari keseluruhan sistem manajemen yang memudahkan manajemen-manajemen risiko $\mathrm{K} 3$ yang berkaitan dengan bisnis organisasi. Hal ini mencakup struktur organisasi aktivitas yang terencana, tanggung jawab, praktek, prosedur, proses dan sumber daya untuk mengembangkan, menerapkan, mencapai, meninjau dan memelihara kebijakan K3 organisasi (OHSAS 18001:1999).

\section{Analisis Keselamatan Kerja}

Akibat kecelakaan kerja paling tidak terdapat dua subsitusi yang dirugikan, pertama kerugian tenaga kerja berupa sakit mungkin cacat tubuh dan tidak masuk kerja untuk berupa hari, sehingga berpengaruh pada absentisme. Kedua kerusakan material atau komponen sumber produksi sehingga sementara waktu tidak dapat operasional dan perlu waktu mengganti suhu cadang.

Secara umum ada dua penyebab terjadinya kecelakaan kerja yaitu :

1. penyebab langsung (immediate causes)

2. penyebab dasar (basic causes)

Langkah pertama dalam proses manajemen risiko adalah melakukan identifikasi bahaya tempat kerja atau tempat yang berpeluang mengalami kerusakan.
Identifikasi bahaya merupakan suatu proses yang dapat dilakukan untuk mengenali seluruh situasi atau kejadian yang berpotensi sebagai penyebab terjadinya kecelakaan dan penyakit akibat kerja yang mungkin timbul di tempat kerja. (Tarwaka, 2008). Identifikasi bahaya di tempat kerja dapat dilakukan dengan cara:

1. Analisis kecelakaan, cidera dan kejadian hampir celaka (near miss).

2. Konsultasi dengan pekerja.

3. Walktrough survey dengan bantuan checklist.

Laboratorium Sistem Tenaga Elektrik adalah satu dari sembilan laboratorium yang berada di Jurusan Teknik Elektro Fakultas Teknik Universitas Lampung. Laboratorium Sistem Tenaga Elektrik melayani pendidikan, penelitian dan pengabdian pada masyarakat bagi mahasiswa, dosen dan masyarakat umum. Untuk kegiatan pendidikan, laboratorium sistem tenaga elektrik praktikum khusus bagi mahasiswa tingkat lanjut (semester ketujuh) yang memilih konsentrasi sistem tenaga listrik dengan mata kuliah praktikum sistem proteksi, transmisi daya elektrik dan analisa sistem tenaga. Untuk mendukung kegiatan praktikum tersebut, laboratorium sistem tenaga elektrik dilengkapi dengan peralatan peralatan berkategori satu,dua dan tiga baik analog maupun digital. Beberapa peralatan tersebut dalam penggunaannya harus di supervisi karena menggunakan sumber tegangan tiga phasa dan tingkat resiko bahaya yang cukup tinggi. Resiko yang dapat terjadi adalah sengatan listrik bertengangan $380 \mathrm{~V}$ yang dapat mengakibatkan cidera bahkan kematian. Untuk mengurangi atau menghilangkan bahaya yang dapat menyebabkan kecelakaan di laboratorium sistem tenaga elektrik maka diperlukan suatu manajemen risiko yang kegiatannya meliputi identifikasi bahaya, analisis potensi bahaya maka penilaian risiko, pengendalian risiko, serta pemantauan dan evaluasi. Dalam proses identifikasi dan melakukan analisis potensi bahaya maka dapat dilakukan dengan menggunakan pendekatan penilaian kuantitatif terhadap potensi bahaya yang diterbitkan oleh Det Norske Veritas. Penelitian ini dilakukan dengan tujuan untuk mengetahui gambaran potensi bahaya dan tingkatan risiko di laboratorium sistem tenaga elektrik serta langkah tindak lanjutnya.

Hasil penelitian ini diharapkan menjadi rekomendasi dan acuan, sehingga dapat dihasilkan prosedur keselamatan dan kesehatan kerja di laboratorium dan panduan evaluasi untuk mengidentifikasi keselamatan kerja di laboratorium sistem tenaga elektrik 


\section{Metode Penelitian}

Metode yang digunakan adalah dengan melakukan penilaian risiko. Proses untuk menentukan prioritas pengendalian terhadap tingkat risiko kecelakaan atau penyakit akibat kerja (Rudi Suardi, 2007:79).

\subsection{Metode Resiko Det Norske Veritas}

Det Norske Veritas adalah metode penilaian kuantitatif terhadap potensi bahaya yang diterbitkan oleh Det Norske Veritas Oslo Norwegia tahun 1997. Pada metode ini telah ditetapkan standar pengukuran potensi bahaya berdasarakan parameter yang ditentukan.

Menentukan peluang insiden yang terjadi di tempat kerja menggunakan skala berdasarkan tingkat potensinya. Berikut ini adalah beberapa faktor yang dapat mempengaruhi peluang terjadinya sebuah insiden:

1. Berapa kali situasi terjadinya

2. Berapa orang yang terpapar

3. Keterampilan dan pengalaman orang yang terluka

4. Berbagai karakteristik khusus personel yang terlibat

5. Durasi paparan
6. Pengaruh posisi seseorang terhadap bahaya

7. Distraksi, tekanan waktu atau kondisi tempat kerja

8. Jumlah material atau tingkat paparan

9. Kondisi lingkungan

10. Kondisi peralatan

11. Efektivitas pengendalian yang ada

Penentuan klasifikasi bahaya mengacu pada parameter peluang resiko berdasarkan $3 \mathrm{D}$ model (tabel 1). Bahaya yang teridientifikasi di laboratorium sistem tenaga elektrik kemudian diinterpretasikan pada standar indeks penilaian resiko (tabel 2).

Tabel 1. Parameter peluang risiko berdasarkan 3D Model

\begin{tabular}{ll}
\hline Sering & Dapat terjadi kapan saja \\
\hline Sangat Sering & $\begin{array}{l}\text { Dapat terjadi secara } \\
\text { berkala }\end{array}$ \\
\hline Sedang & $\begin{array}{l}\text { Dapat terjadi pada } \\
\text { kondisi tertentu }\end{array}$ \\
\hline Jarang & Dapat terjadi, tapi jarang \\
\hline Sangat Jarang & $\begin{array}{l}\text { Memungkinkan tidak } \\
\text { pernah terjadi }\end{array}$ \\
\hline
\end{tabular}

Tabel 2. Standar indeks penilaian resiko

\begin{tabular}{lcccccc}
\hline \multicolumn{1}{c}{ Paparan } & Peluang & & Konsekuensi & & Nilai Resiko \\
\hline Terus Menerus & 10 & $\begin{array}{c}\text { Sangat } \\
\text { sering }\end{array}$ & 1 & Fatal & 20 & E > 20 \\
\hline Berkala & 6 & Sering & 0.6 & Major & 10 & H > 10 \\
\hline Tertentu & 3 & Sedang & 0.3 & Sedang & 5 & M 3-10 \\
\hline Tidak Teratur & 2 & Jarang & 0.1 & Minor & 2 & L $<3$ \\
\hline Jarang & 1 & $\begin{array}{c}\text { Sangat } \\
\text { Jarang }\end{array}$ & 0.05 & $\begin{array}{c}\text { Tidak } \\
\text { Signifikan }\end{array}$ & 1 & - \\
\hline
\end{tabular}

Keterangan:

$\begin{array}{ll}\mathrm{E} & \text { : Ekstrim atau Signifikan } \\ \mathrm{H} & \text { : Risiko Tinggi } \\ \mathrm{M} & \text { : Risiko Sedang } \\ \mathrm{L} & \text { : Risiko Rendah }\end{array}$

Untuk menentukan konsekuensi, kita harus membuat ketetapan pada severity yang berpotensi terjadi berdasarkan framework penelitian bahaya di laboratorium (gambar 1). Faktor-faktor yang dapat mempengaruhi konsekuensi yang harus dipertimbangkan:

1. Potensi pada reaksi berantai, dimana sebuah bahaya jika tidak dihilangkan, akan mengakibatkan kondisi yang lebih berat.

2. Konsentrasi Substansi

3. Volume Material

4. Kecepatan proyektil dan pergerakan bagiannya
5. Ketinggian, akibat yang dihasilkan dari benda yang jatuh ditentukan dari benda itu semula,

begitu pula orang yang jatuh dari ketinggian.

6. Jarak pekerja dari bahaya potensial

7. Berat, untuk kejadian tertimpa benda sangat dipengaruhi berat benda tersebut.

8. Tingkat gaya dan energi. Misalnya semakin tinggi volume listrik semakin tinggi akibat yang dihasilkan jika tersetrum 


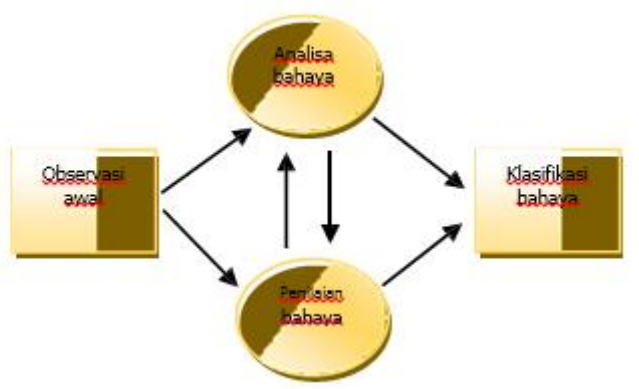

Gambar 1. Framework penilaian bahaya di laboratorium.

Pada hasil pengamatan dan identifikasi dilakukan pengukuran dengan menggunakan metode penilaian kuantitatif terhadap potensi bahaya yang diterbitkan oleh Det Norske Veritas Oslo Norwegia tahun 1997.

2.2 Metode Penilaian Bahaya Secara Kuntitatif 3D

Sebagai pembanding, penilaian dilakukan juga dengan menggunakan metode 3D dengan tabel penilaian seperti pada gambar 2 .

\begin{tabular}{|c|c|c|c|c|}
\hline \multirow{2}{*}{$\begin{array}{l}\text { Buhaygyg } \\
\text { dididentif iksi }\end{array}$} & & dian Risilito & Nili2i & \multirow[b]{2}{*}{$\begin{array}{l}\text { Tightatu } \\
\text { Rislio }\end{array}$} \\
\hline & $\begin{array}{c}\text { Pppun } \\
\text { (\$) }\end{array}$ & 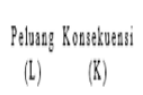 & $\begin{array}{c}\text { Risito ExLs } \\
\mathbb{R}\end{array}$ & \\
\hline
\end{tabular}

Gambar 2. Table penilaian resiko 3D model

3D model menampilkan 3 parameter untuk penilaian tingkat resiko dari objek yang di observasi yakni peluan (tabel 3), kuantitas kejadian (tabel 4), tingkat kegawatan (tabel 5) dan standar nilai klasifikasi resiko (tabel 6).

Tabel 3. Peluang risiko berdasarkan Det Noske Veritas

\begin{tabular}{lc}
\hline \multicolumn{1}{c}{ Nilai Kemungkinan terjadi (A) } & Nilai \\
\hline $\begin{array}{l}\text { A1 - Sering terjadi ( terjadi 1 kali } \\
\text { dalam 10 kali kempatan ) }\end{array}$ & 10 \\
\hline $\begin{array}{l}\text { A2 - Cukup memungkinkan ( 1kali dalam } \\
\text { 100 kesempatan ) }\end{array}$ & 6 \\
\hline $\begin{array}{l}\text { A3 - Tak biasa tapi memungkinkan ( 1 } \\
\text { kali dalam 1000 kesempatan ) }\end{array}$ & 3 \\
\hline $\begin{array}{l}\text { A4 - Pernah terjadi di tempat lain ( 1 } \\
\text { kali dalam 10000 kesempatan ) }\end{array}$ & 1 \\
\hline $\begin{array}{l}\text { A5 - Belum pernah terjadi ( 1 kali dalam } \\
\text { 100000 kesempatan ) }\end{array}$ & 0.5 \\
\hline $\begin{array}{l}\text { A6 - Secara praktis tidak mungkin ( 1 } \\
\text { kali dalam 1000000 kesempatan ) }\end{array}$ & 0.2 \\
\hline A7 - Tidak mungkin & 0.1 \\
\hline
\end{tabular}

Tabel 4. Kuantitas kejadian

\begin{tabular}{llc}
\hline \multicolumn{1}{c}{ Kuantitas Kejadian (B) } & Nilai \\
\hline B1 & -Terus menerus ... ( beberapa & 10 \\
kali dalam & \\
\hline B2 & -Sering ( sekali dalam sehari ) & 6 \\
\hline B3 & -Kadang kadang ( sekali dalam & 3 \\
\hline B4 & -Tak biasa ( sekali dalam setahun ) & 2 \\
\hline B5 & -Jarang ( beberapa kali dalam setahun & 1 \\
\hline B6 & -Sangat Jarang (sekali dalam setahun ) & 0.5 \\
\hline B7 & -Tak pernah terpapar & 0 \\
\hline
\end{tabular}

Tabel 5. Tingkat kegawatan

\begin{tabular}{lc}
\hline $\begin{array}{l}\text { Tingkat kegawatan (Akibat yang } \\
\text { ditimbulkan ) }(\mathbf{C})\end{array}$ & Nilai \\
\hline $\begin{array}{l}\text { C1 - Bencana Alam ( banyak korban } \\
\text { jiwa, nilai kerusakan ) }\end{array}$ & 100 \\
\hline $\begin{array}{l}\text { C2 - Malapetaka ( beberapa korban } \\
\text { jiwa, nilai kerusakaan ) }\end{array}$ & 40 \\
\hline $\begin{array}{l}\text { C3 - Sangat serius ( satu } \\
\text { kematian, nilai kerusakan ) }\end{array}$ & 15 \\
\hline $\begin{array}{l}\text { C4 - Serius ( cedera serius, cacat } \\
\text { tetap, nilai kerusakan ) }\end{array}$ & 7 \\
\hline $\begin{array}{l}\text { C5 - Penting ( cedera sementara, } \\
\text { hilang kerja, nilai kerusakan) }\end{array}$ & 3 \\
\hline $\begin{array}{l}\text { C6 - Dapat dicatat ( cedera ringan / } \\
\text { P3K, nilai kerusakan) }\end{array}$ & 1 \\
\hline
\end{tabular}

Nilai Risiko $\mathrm{NR}=\mathrm{A}$ x $\mathrm{B}$ x $\mathrm{C}$ Nilai risiko (besarnya Risiko) adalah perkalian nilai kemungkinan terjadi (A) dikali nilai seringnya terpapar (B) dikali nilai tingkat kegawatannya (C)

Tabel 6. Standar nilai dan klasifikasi resiko

\begin{tabular}{cl}
\hline NILAI & KLASIFIKASI RESIKO \\
\hline$>$ & $\begin{array}{l}\text { Risiko sangat tinggi, operasi } \\
\text { harus dihentikan }\end{array}$ \\
\hline 400 & $\begin{array}{l}\text { Risiko tinggi, diperlukan } \\
\text { perbaikan segera }\end{array}$ \\
\hline $200-400$ & Risiko sedang, perlu perbaikan \\
\hline $70-200$ & $\begin{array}{l}\text { Risiko sedang dapat } \\
\text { terjadi, perlu perhatian }\end{array}$ \\
\hline $20-70$ & $\begin{array}{l}\text { Risiko kecil, dapat } \\
\text { diterima apa adanya }\end{array}$ \\
\hline$<20$
\end{tabular}

\section{Hasil dan Pembahasan \\ 3.1 Penentuan klasifikasi bahaya}

Prosedur yang digunakan dalam identifikasi bahaya adalah (1) mengamati dan menganalisa secara langsung terhadap peralatan, bahan dan fasilitas di laboratorium sistem tenaga elektrik yang rutin digunakan dan memiliki potensi bahaya (2) data hasil pengamatan dan anlisa kemudian dilakukan penilaian sesuai dengan metode penilaian yang digunakan (3) selanjutnya hasil penilaian diklasifikasikan untuk menentukan tingkat 
bahaya yang ada di laboratorium. Ada beberapa jenis-bahaya yang perlu diketahui antara lain :

1. Bahaya Benda Bergerak (kinetic hazards)

2. Bahaya Benda Diam (static hazards)

3. Bahaya Benda Fisik (physical hazards)

4. Bahaya Listrik (electrical hazards)

5. Bahaya Kimiawi (chemical hazards)

6. Bahaya Biologis (biological hazards)
7. Bahaya Ergonomis (ergonomics hazard)

8. Bahaya Psikologis (psychological hazards)

\subsection{Metode Penilaian Bahaya Det Noske Veritas dan Model 3D}

Dengan menggunakan metode penilaian bahaya det norske veritas, identifikasi dan penilaian potensi bahaya laboratorium yang ditunjukkan oleh tabel berikut :

Tabel 8. Contoh hasil identifikasi dan penilaian risiko dengan metode Det Noske Veritas (table 4.5.6 dan 7)

\begin{tabular}{|c|c|c|c|c|c|c|}
\hline \multirow{2}{*}{ No } & \multicolumn{5}{|c|}{ Nilai Bahaya } & \\
\hline & $\begin{array}{c}\text { Bahan dan } \\
\text { Fasilitas }\end{array}$ & Peluang & Kuantitas & $\begin{array}{c}\text { Kegawat } \\
\text { an }\end{array}$ & $\begin{array}{l}\text { Total } \\
\text { Nilai }\end{array}$ & Klasifikasi Bahaya \\
\hline
\end{tabular}

\begin{tabular}{l|ccccc}
\hline 1 & $\begin{array}{c}\text { A2- Cukup } \\
\text { memungkinkan }\end{array}$ & $\begin{array}{c}\text { B6-Sangat } \\
\text { Jarang (sekali } \\
\text { dalam setahun) }\end{array}$ & - Serius & C4 & $\begin{array}{c}\text { Risiko dapat terjadi, } \\
\text { perlu perhatian }\end{array}$ \\
\hline
\end{tabular}

\begin{tabular}{|c|c|c|c|c|c|c|}
\hline 2 & 8 & $\begin{array}{c}\text { A2- Cukup } \\
\text { memungkinkan }\end{array}$ & $\begin{array}{c}\text { B6 - Sangat } \\
\text { Jarang (sekali } \\
\text { dalam setahun) }\end{array}$ & $\begin{array}{c}\text { C4 } \\
\text { - Serius }\end{array}$ & 21 & $\begin{array}{c}\text { Risiko dapat terjadi, } \\
\text { perlu perhatian }\end{array}$ \\
\hline 3 & & $\begin{array}{c}\text { A2- Cukup } \\
\text { memungkinkan }\end{array}$ & $\begin{array}{c}\text { B6 - Sangat } \\
\text { Jarang (sekali } \\
\text { dalam setahun) }\end{array}$ & $\begin{array}{c}\text { C4 } \\
\text { - Serius }\end{array}$ & 21 & $\begin{array}{l}\text { Risiko dapat terjadi, } \\
\text { perlu perhatian }\end{array}$ \\
\hline
\end{tabular}

\begin{tabular}{|c|c|c|c|c|c|c|}
\hline 4 & & $\begin{array}{c}\text { A2- Cukup } \\
\text { memungkinkan }\end{array}$ & $\begin{array}{c}\text { B6 - Sangat } \\
\text { Jarang (sekali } \\
\text { dalam setahun) }\end{array}$ & $\begin{array}{c}\text { C4 } \\
\text { - Serius }\end{array}$ & 21 & $\begin{array}{l}\text { Risiko dapat terjadi, } \\
\text { perlu perhatian }\end{array}$ \\
\hline 5 & & $\begin{array}{l}\text { A2- Cukup } \\
\text { memungkinkan }\end{array}$ & $\begin{array}{c}\text { B6 - Sangat } \\
\text { Jarang (sekali } \\
\text { dalam setahun) }\end{array}$ & $\begin{array}{c}\text { C4 } \\
\text { - Serius }\end{array}$ & 21 & $\begin{array}{c}\text { Risiko dapat terjadi, } \\
\text { perlu perhatian }\end{array}$ \\
\hline 6 & 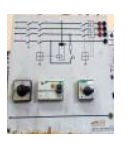 & $\begin{array}{l}\text { A2- Cukup } \\
\text { memungkinkan }\end{array}$ & $\begin{array}{c}\text { B6 - Sangat } \\
\text { Jarang (sekali } \\
\text { dalam setahun) }\end{array}$ & $\begin{array}{c}\text { C4 } \\
\text { - Serius }\end{array}$ & 21 & $\begin{array}{c}\text { Risiko dapat terjadi, } \\
\text { perlu perhat an }\end{array}$ \\
\hline 7 & 1090 & $\begin{array}{c}\text { A6 - Secara praktis } \\
\text { tidak mungkin } \\
(1 \text { kali dalam } \\
1000000 \\
\text { kesempatan })\end{array}$ & $\begin{array}{c}\text { B6 - Sangat } \\
\text { Jarang (sekali } \\
\text { dalam setahun) }\end{array}$ & $\begin{array}{c}\text { C4 } \\
\text { - Serius }\end{array}$ & 0.7 & $\begin{array}{l}\text { Risiko kecil, dapat } \\
\text { diterima apa adanya }\end{array}$ \\
\hline
\end{tabular}




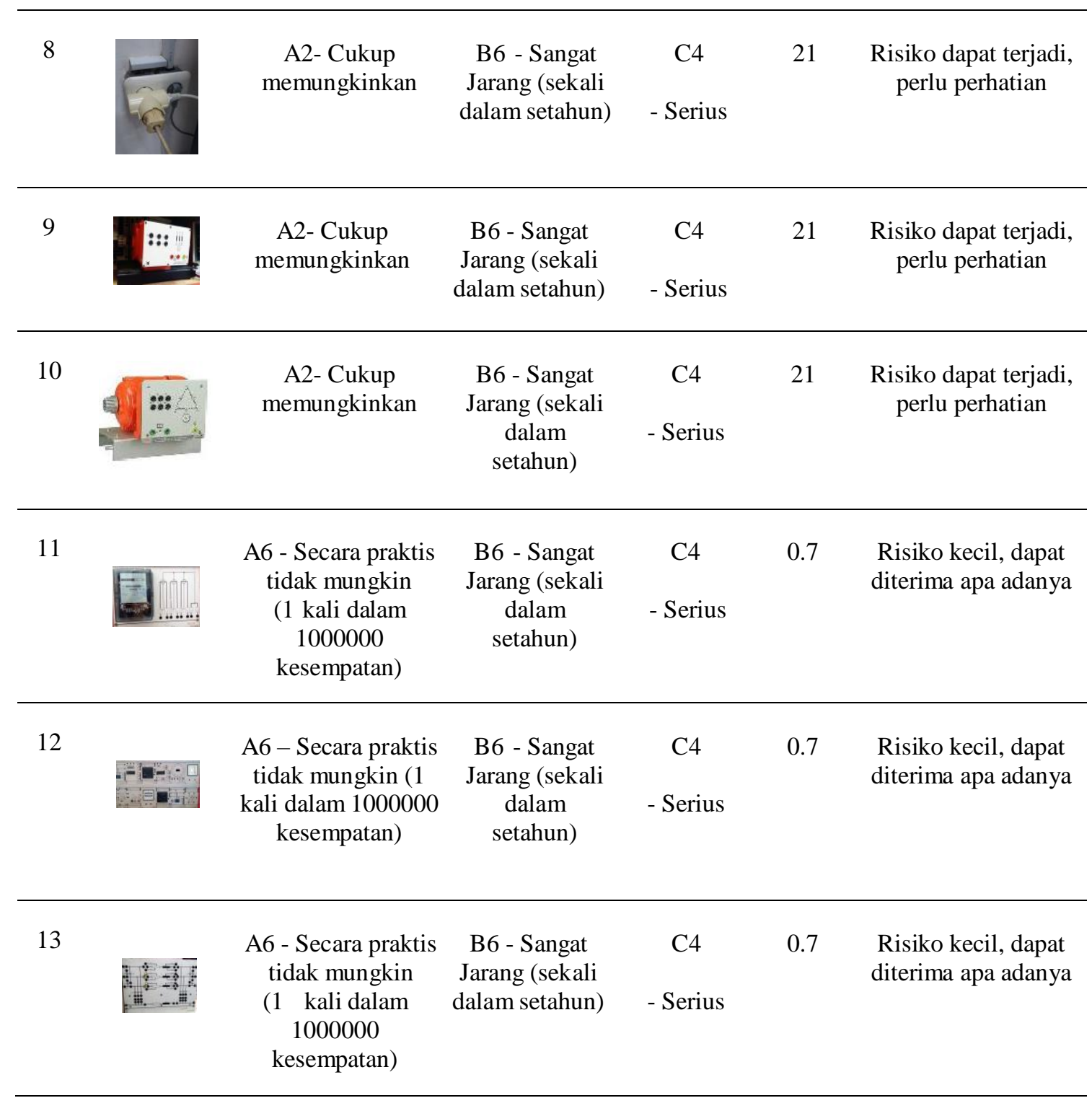

Berdasarkan hasil identifikasi penilaian resiko dengan metode Det Noske Veritas (mengacu pada tabel 2 dan 8) didaptkan $31 \%$ potensi biaya kecil dan $69 \%$ potensi bahaya sedang yang terjadi di laboratorium sistem tenaga elektrik yang ditampilan pada pie chart (gambar 3). Potensi bahaya tersebut bersumber dari 13 peralatan yang digunakan di laboratorium sistem tenaga elektrik

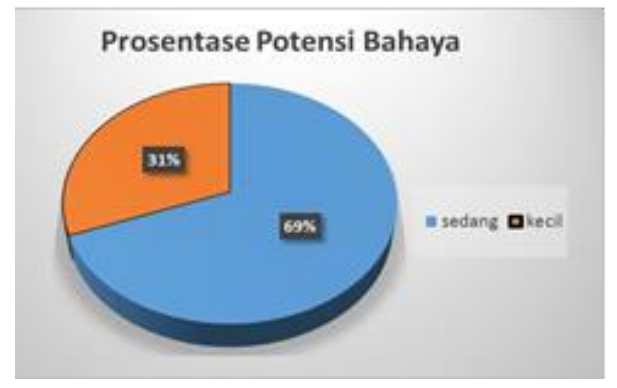

Gambar 3. Penilaian potensi bahaya dengan Det Norske Veritas

Dengan menggunakan metode penilaian bahaya 3D model, identifikasi dan penilaian potensi bahaya laboratorium yang ditunjukkan oleh table 9: 
Tabel 9. Contoh hasil identifikasi dan penilaian risiko dengan metode 3D Model (table 1,2 dan 3)

\begin{tabular}{|c|c|c|c|c|c|c|}
\hline & & & Nilai bahay & & & \\
\hline No & $\begin{array}{c}\text { Jenis Alat, } \\
\text { Bahan dan } \\
\text { Fasilitas }\end{array}$ & Paparan & Peluang & $\underset{\text { nsi }}{\text { Konsekue }}$ & $\begin{array}{l}\text { Total } \\
\text { Nilai }\end{array}$ & Klasifikasi Bahaya \\
\hline 1 & III & Jarang (1) & Sering (0.6) & Mayor (10) & 6 & Risiko sedang \\
\hline 2 & & Jarang (1) & Sering (0.6) & Mayor (10) & 6 & Risiko sedang \\
\hline 3 & & Jarang (1) & Sering (0.6) & Mayor (10) & 6 & Risiko sedang \\
\hline 4 & & Jarang (1) & Sering (0.6) & Minor (2) & 1.2 & Risiko rendah \\
\hline 5 & & Jarang (1) & Sering (0.6) & Mayor (10) & 6 & Risiko sedang \\
\hline 6 & & Jarang (1) & Sering (0.6) & Mayor (10) & 6 & Risiko sedang \\
\hline 7 & & Jarang (1) & Sering (0.6) & Minor (2) & 1.2 & Risiko rendah \\
\hline 8 & & Jarang (1) & Sering (0.6) & Minor (2) & 1.2 & Risiko rendah \\
\hline 9 & & Jarang (1) & Sering (0.6) & Mayor (10) & 6 & Risiko sedang \\
\hline 10 & & Jarang (1) & Sering (0.6) & Mayor (10) & 6 & Risiko sedang \\
\hline
\end{tabular}

$11 \quad$ Jarang (1) Sering (0.6) Mayor (10) 6 Risiko sedang 


\begin{tabular}{llllll}
\hline 12 & Jarang (1) & Sering (0.6) & Minor (2) & 1.2 & Risiko rendah \\
\hline & Jarang (1) & Sering (0.6) & Minor (2) & 1.2 & Risiko rendah
\end{tabular}

Bila dilihat dari kedua tabel hasil penilaian bahaya, klasifikasi bahaya di laboratorium sistem tenaga elektrik digolongkan pada tingkat rendah dan sedang (mengacu pada tabel 2 dan tabel 9). Namun demikian, potensi bahaya tersebut tetap membutuhkan perhatian dari pengelola dan pengguna laboratorium (table 6). Dari hasil identifikasi, dilaboratorium sistem tenaga elektrik belum dapat mengetahui potensi bahaya yang dihadapi.

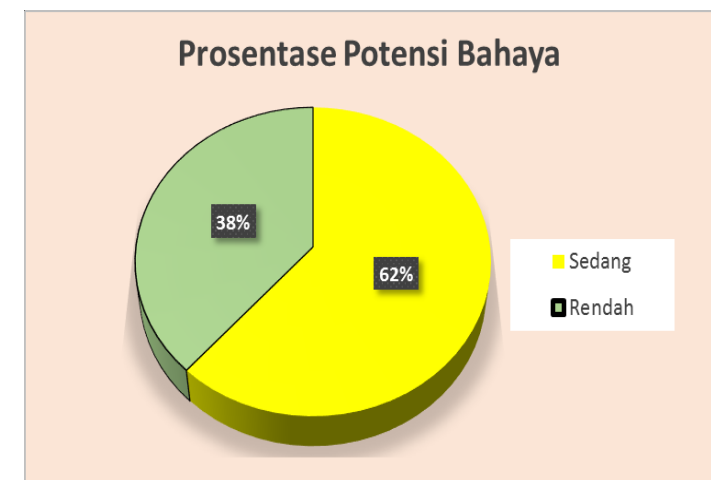

Gambar 4. Penilaian potensi bahaya dengan 3D Model

Hasil identifikasi bahaya yang dilakukan pada laboratorium sistem tenaga elektrik, direkomendasikan untuk memasang ramburambu di area laboratorium sistem tenaga elektrik antara lain :

1. Rambu-rambu peringatan (contoh)
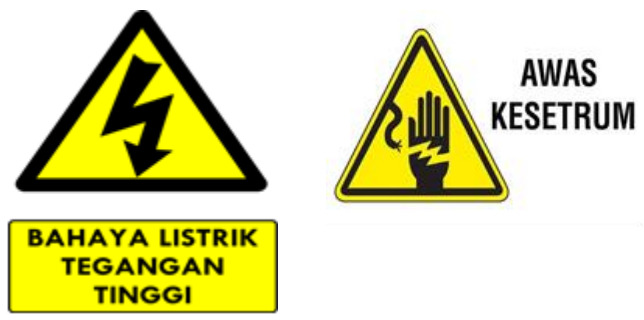

Pemasangan rambu peringatan dimaksudkan untuk mengingatkan kepada pengguna laboratorium terkait risiko bahaya saat melakukan aktivitas laboratorium.
2. Rambu rambu larangan (contoh)

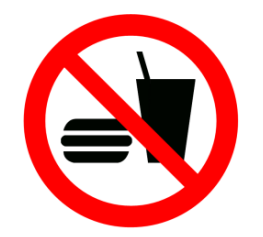

DILARANG MEMBAWA MAKANAN/MINUMAN

3. Laboratorium dimaksudkan sebagai informasi terkait perilaku dan aktivitas yang tidak boleh dilakukan pengguna laboratorium selama berada di laboratorium.

4. Rambu-rambu perintah contoh :
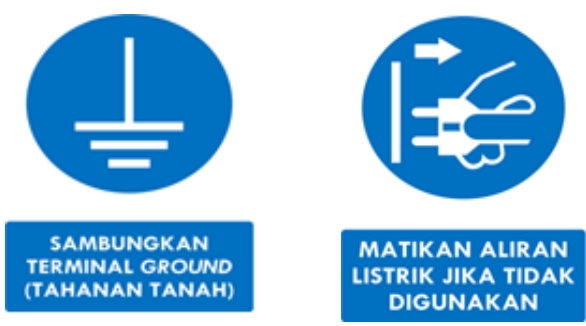

\section{Kesimpulan}

1. Dari hasil identifikasi dan penilaian risiko bahaya di Laboratorium Sistem Tenaga Elektrik diketahui bahwa potensi risiko bahaya berada dilevel bahaya sedang dan rendah.

2. Pengendalian yang perlu dilakukan di Laboratorium Sistem Tenaga Elektrik adalah penyediaan alat pengaman diri (APD), instruksi keselamatan kerja dan pemasangan rambu keselamatan.

\section{Daftar Pustaka}

OSH Administration, Job Hazard Analysis OSHA 3071 US: Departement of Labor,2002. hhtp://www.osha.gov/publications/osha3071

Suardi R. 2007.Sistem Manajemen Kesehatan dan Keselamatan Kerja. Jakarta. 
Sholiha, Qomariyatus dan Fauzia, Rahmi. 2015. Keselamatan dan Kesehatan Kerja (K3) Sekolah. Malang: UB Press.

Sulistyarini, Wahyu Ratna. 2006. Pengaruh Program Keselamatan dan Kesehatan Kerja terhadap Produktivitas Karyawan Pada CV Sahabat Klaten. Sekolah Tinggi Agama Islam Negeri. Diambil pada 20 September 2012 dari idb4.wikispaces.com/file/view/rd4005.pdf

Sitorus, Artia T. 2010. Identifikasi Bahaya Dan Penilaian Risiko Keselamatan Dan Kesehatan Kerja Tahun 2009 (Studi Kasus di Unit Utility PT. SK. Keris Banten). Semarang. Universitas Negeri Semarang.

Zulliyanti S. 2010. Pengaruh Perilaku Pekerja terhadap penerapan manajemen Keselamatan dan Kesehatan Kerja di bagian produksi PT. Gold Coin Indonesia tahun 2010. Medan: Universitas Sumatera Utara Fakultas Kesehatan Masyarakat (tesis). 